\title{
A prospective comparative study to evaluate the efficacy of ultrasonography and hysteroscopy and their correlation with the histopathology of endometrium in a case of abnormal uterine bleeding
}

\author{
Madhu Kumari*, Alka S. Gupta \\ Department of Obstetrics \& Gynaecology, Seth G.S. Medical College \& KEM Hospital, Mumbai, Maharashtra, India
}

Received: 22 September 2015

Accepted: 30 October 2015

*Correspondence:

Dr. Madhu Kumari,

E-mail: mk0222013@gmail.com

Copyright: ( $)$ the author(s), publisher and licensee Medip Academy. This is an open-access article distributed under the terms of the Creative Commons Attribution Non-Commercial License, which permits unrestricted non-commercial use, distribution, and reproduction in any medium, provided the original work is properly cited.

\begin{abstract}
Background: Abnormal uterine bleeding (AUB) is one of the most common complaints that brings a woman to the gynecologist. Key to successful clinical management of AUB is to identify the cause behind it for which proper evaluation of the case is required. In current scenario of increasing cost awareness and taking risk related to invasive procedure hysteroscopy, a balance has to be achieved between the practices of randomly doing all investigation versus a condition appropriate approach. This study was done to compare efficacy of pelvic ultrasonography \& hysteroscopy in cases of AUB and their correlation with the histopathology of endometrium.

Methods: In this study 70 women with AUB were selected as they presented in OPD. After evaluation of clinical presentation, general, systemic and local examination, ultrasonography and hysteroscopy were performed on every patient and endometrial curetting were sent for histopathology.

Results: We concluded that ultrasonography has a better efficacy to detect uterine cause of AUB and hysteroscopy is better for detecting intracavitary lesions.

Conclusions: Ultrasonography has a better efficacy to detect uterine cause of AUB. However a thorough history and detailed clinical examination plays a very important role in narrowing the differential diagnosis of AUB. We have developed an algorithmic approach and guidelines for selective use of hysteroscopy in cases of AUB after evaluating the results.
\end{abstract}

Keywords: Abnormal uterine bleeding, AUB, Ultrasonography, Hysteroscopy, Histopathology, Endometrium.

\section{INTRODUCTION}

Abnormal uterine bleeding (AUB) is bleeding from the uterus that is not normal in amount, frequency, duration and setting of occurrence. Though it is often used to describe abnormal uterine bleeding during reproductive years, it also refers to any uterine bleeding after menopause.

Abnormal uterine bleeding accounts for a significant proportion of gynecological referral and is caused by wide range of pathologies. Key to successful clinical management of abnormal uterine bleeding is to identify the cause behind it for which proper evaluation of the case is required.

Problem is evaluated by the followings.

1. Careful and detailed history taking

2. Physical examination

3. Investigation

A careful history and physical examination helps to narrow down the differential diagnosis and further 
investigation is required to finalize the pathology causing the bleeding.

Common investigation required are:

1. Biochemical and serological studies.

2. Vaginal cytology (Pap smear)

3. Endometrial brush cytology ${ }^{1}$

4. Pelvic sonography ${ }^{2-5}$

5. Diagnostic hysteroscopy ${ }^{6,7}$

6. Histopathological evaluation ${ }^{8}$

In current scenario of increasing cost awareness \& taking risk related to invasive procedure like sepsis, need of possible anesthesia for hysteroscopy, trauma during hysteroscopy a balance has to be achieved between the practice of randomly doing all investigation versus a condition appropriate approach.

This study will help us to narrow down the list of investigation required to detect the specific causes of abnormal uterine bleeding.

It will also aid to develop a guideline for the assessment of AUB. That will help patient in early diagnosis of the cause and hence early treatment in a very cost effective and less invasive way. It will also help to know the patients who are likely to be benefited most by the invasive procedure of hysteroscopy.

\section{METHODS}

This study was a prospective, non-blinded, randomized, controlled trial conducted at a tertiary care hospital during October 2012 to October 2013.

Study group: A total number of 70 patients who presented to the outpatient department with complaints of vaginal bleeding were selected and evaluated for abnormal uterine bleeding.

Sample size: A total number of 70 patients were evaluated for abnormal uterine bleeding.

Inclusion criteria: Women presenting with abnormal uterine bleeding, postmenopausal bleeding and post coital bleeding and who had all investigations performed in this tertiary care hospital only were included.

Exclusion criteria: 1. Uterine bleeding due to systemic disorder like liver dysfunction, thyroid disease, renal disease, and bleeding disorders; 2. Any drug induced bleeding; 3. Unmarried girls (virgins).

Study procedure was explained to each and every patient. Written, informed, valid consent was taken. It was followed by recording a detailed and complete history and examination. Case record form documented the following points: age, chief complaints, duration of complaints, past menstrual history, chronic medical illness, bleeding disorder, and general, systemic, abdominal and local pelvic examination. Investigations like Hemoglobin, WBC, platelet count, bleeding and clotting time, serum TSH, Pap smear and Endometrial brush cytology was done for all the patients of AUB. All patients were further assessed by performing a pelvic ultrasonography, hysteroscopy and histopathological study of the endometrium obtained by dilatation \& curettage.

Ultrasonography (USG): Ultrasonography was performed by a radiology resident doctor, a fellow or a staff member using $3.5 \mathrm{MHz}$ probe. First transabdominal scan was done on a full bladder and then if required a transvaginal scan was done on an empty bladder. Pelvic anatomy was studied. Dimension of uterus, adnexal masses, appearance of endometrium, its thickness, intracavitary lesions, were noted. Specific notes regarding the presence or suspicion of fibroid, polyp, hyperplasia, malignancy and any other pathology were documented.

Hysteroscopy: Each patient was admitted in ward and was prepared prior to surgery after taking written informed valid consent. Patient was then posted for hysteroscopy. Hysteroscopy was done by a consultant gynecologist under intravenous sedation administered by an anesthetist. Diagnostic hysteroscopy was performed using $5 \mathrm{~mm}$ rigid fiber-optic hysteroscope. Normal saline was used as a distending medium. Hysteroscopy findings were documented. Dilatation and curettage was done after the diagnostic hysteroscopy and an endometrial sample was then sent for histopathology examination

The result of histopathology was taken as gold standard and sensitivity \& specificity of USG \& hysteroscopy in detecting the intrauterine abnormality were calculated.

Statistical analysis: Analysis was done by calculating sensitivity, specificity, positive predictive value and negative predictive value of ultrasonography and diagnostic hysteroscopy as evaluation modality in comparison to endometrial histopathology report.

\section{RESULTS}

It was observed in our research that incidence of abnormal uterine bleeding is more common in the age group of 31 to 50 years and constitute almost $68 \%$ of cases of abnormal uterine bleeding as shown in Table 1.

Table 1: Age distribution of AUB.

\begin{tabular}{|ll|l|}
\hline Age (years) & No of cases & Percent \\
$\leq 20$ & 1 & 1.4 \\
\hline $21-30$ & 16 & 22.9 \\
\hline $31-40$ & 26 & 37.1 \\
\hline $41-50$ & 22 & 31.4 \\
\hline$>50$ & 5 & 7.1 \\
\hline Total & 70 & 100.0 \\
\hline
\end{tabular}


Table 2: Frequency of different type of AUB.

\begin{tabular}{|lcc|}
\hline Clinical Features & No of cases & Percent \\
\hline Hypomenorrhea & 2 & 2.9 \\
\hline Oligomenorrhagia & 1 & 1.4 \\
\hline Oligomenorrhea & 10 & 14.3 \\
\hline Amenorrhea & 3 & 4.3 \\
\hline Intermenstrual bleeding & 1 & 1.4 \\
\hline Menometrorrhagia & 4 & 5.8 \\
\hline Menorrhagia & 27 & 38.6 \\
\hline Polymenorrhagia & 17 & 24.3 \\
\hline Polymenorrhea & 1 & 1.4 \\
\hline Post menopausal bleeding & 4 & 4.7 \\
\hline Total & 70 & 100.0 \\
\hline
\end{tabular}

Among the different type of abnormal uterine bleeding menorrhagia is most common and constitute almost $40 \%$ of the cases, polymenorrhagia constitute the second most common presenting symptom and constitute $24 \%$ of the total cases as shown in Table 2 .

In different age group different form of abnormal uterine bleeding is common, in age group $<20$ and 21-30 oligo menorrhea is common, however in age group of 31-40 menorrhagia is the most common complain followed by polymenorrhagia, in age group of 41-50 polymenorrhagia is the most common complain followed by menorrhagia, and in the age group of $>50$ postmenopausal spotting and menorrhagia is common, postmenopausal spotting forms $40 \%$ of complain in the age group of $>50$ years as shown in Table 3. Most of the patient had a normal past menstrual cycle.

Abnormal uterine bleeding is more common in multigravidas as shown in Table 4.

In 30 cases USG is suggestive of a uterine cause of AUB and in remaining 40 cases it suggests dysfunctional uterine bleeding as a cause of AUB. The data were then compared with histopathology to know the accuracy of USG in Table 5.

In Table 6, $\mathrm{N}$ is 68 as in two cases sample for histopathology was scanty and sample was inadequate for histopathology examination. The above table shows 57\% cases had secretory endometrium in cases of AUB, hence more than half of the cases of uterine pathology (local uterine factor) is the cause of AUB and not the endocrine (ovarian) dysfunction.

Table 3: Distribution of different type of abnormal uterine bleeding in different age group.

\begin{tabular}{|c|c|c|c|c|c|c|c|c|c|c|c|c|c|}
\hline \multirow{2}{*}{\multicolumn{2}{|c|}{$\begin{array}{l}\text { Age } \\
\text { group } \\
\text { years }\end{array}$}} & \multirow[b]{2}{*}{$\begin{array}{c}\text { Hypom } \\
\text { enorrhe } \\
\text { a }\end{array}$} & \multirow[b]{2}{*}{$\begin{array}{l}\text { Menomet } \\
\text { rorrhagia }\end{array}$} & \multirow[b]{2}{*}{$\begin{array}{c}\text { Oligome } \\
\text { norrhagi } \\
\text { a }\end{array}$} & \multirow[b]{2}{*}{$\begin{array}{c}\text { Oligom } \\
\text { enorrhe } \\
\mathrm{a}\end{array}$} & \multirow[b]{2}{*}{$\begin{array}{c}\text { Post- } \\
\text { menopau } \\
\text { sal } \\
\text { spotting }\end{array}$} & \multirow[b]{2}{*}{$\begin{array}{l}\text { Amen } \\
\text { orrhea }\end{array}$} & \multirow[b]{2}{*}{$\begin{array}{c}\text { Interme } \\
\text { nstrual } \\
\text { bleeding }\end{array}$} & \multirow[b]{2}{*}{$\begin{array}{l}\text { Meno } \\
\text { metror } \\
\text { rhagia }\end{array}$} & \multirow[b]{2}{*}{$\begin{array}{l}\text { Menor } \\
\text { rhagia }\end{array}$} & \multirow[b]{2}{*}{$\begin{array}{c}\text { Polym } \\
\text { enorrh } \\
\text { agia }\end{array}$} & \multirow[b]{2}{*}{$\begin{array}{c}\text { Polym } \\
\text { enorrh } \\
\text { ea }\end{array}$} & \multirow[t]{2}{*}{ Total } \\
\hline & & & & & & & & & & & & & \\
\hline$<20$ & $\mathrm{~N}$ & 0 & 0 & 0 & 1 & 0 & 0 & 0 & 0 & 0 & 0 & 0 & 1 \\
\hline $21-30$ & $\mathrm{~N}$ & 1 & 1 & 0 & 8 & 0 & 1 & 1 & 0 & 1 & 2 & 1 & 16 \\
\hline $41-50$ & $\mathrm{~N}$ & 0 & 1 & 0 & 0 & 2 & 0 & 0 & 0 & 10 & 9 & 0 & 22 \\
\hline$>50$ & $\mathrm{~N}$ & 0 & 0 & 0 & 0 & 2 & 0 & 0 & 0 & 2 & 1 & 0 & 5 \\
\hline Total & $\mathrm{N}$ & 2 & 2 & 1 & 10 & 4 & 3 & 1 & 2 & 27 & 17 & 1 & 70 \\
\hline
\end{tabular}

$\mathrm{N}$ : Number of patients

Here $\mathrm{N}$ is 66 because in 2 cases sample for histopathology is inadequate, and in another two samples histopathology report is atrophic endometrium and interval phase of endometrium respectively. Both these patients had a normal size uterus. Out of 66 cases when compared with histopathology report of the endometrium USG is able to detect 21 cases of uterine cause of AUB accurately. Twenty (20) cases of dysfunctional uterine bleeding (DUB) were truly diagnosed by USG, hence the accuracy of USG that is sensitivity to detect AUB is $63.23 \%$. Specificity to detect uterine cause is $78 \%$, positive predictive value for uterine cause of AUB is $75 \%$, and negative predictive value for uterine cause of AUB is 55\% in Table 7 and Figure 1.

Sensitivity of hysteroscopy to diagnose the cause (uterine + DUB) of AUB is $45.45 \%$. Specificity to detect uterine cause is $77.8 \%$, positive predictive value for uterine cause of AUB is $60 \%$, and negative predictive value for uterine cause of AUB is $41 \%$ in Table 8 and Figure 2.

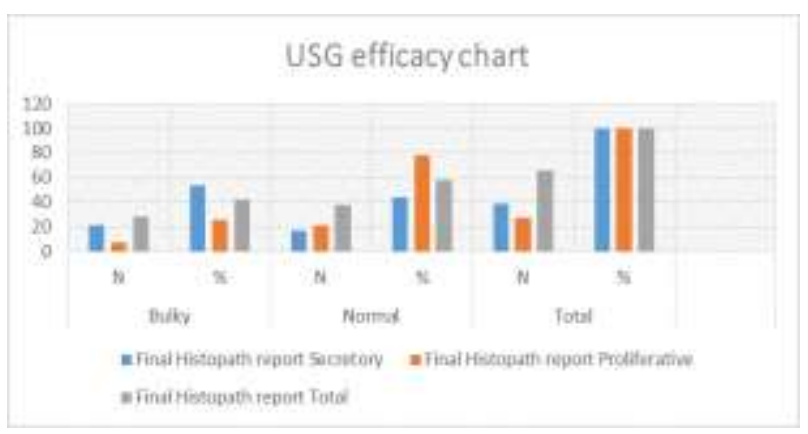

Figure 1: USG efficacy chart. 
Table 4: Parity wise distribution of AUB.

\begin{tabular}{|lll|}
\hline Parity & No. of cases & Percentage \\
\hline Multi & 43 & 61.4 \\
\hline Nulligravida & 16 & 22.9 \\
\hline Primigravida & 11 & 15.7 \\
\hline Total & 70 & 100 \\
\hline
\end{tabular}

Table 5: Ultrasonography findings.

\begin{tabular}{|llc|}
\hline USG & No. of cases & Percentage \\
\hline Normal & 38 & 54.28 \\
\hline Fibroid & 10 & 14.28 \\
\hline Bulky & 8 & 11.4 \\
\hline Adenomyosis & 6 & 8.57 \\
\hline Polyp & 6 & 8.57 \\
\hline PCOD (normal size uterus) & 2 & 2.85 \\
\hline Total & 70 & 100 \\
\hline
\end{tabular}

Table 6: Final histopathology report chart.

\begin{tabular}{|lcc|}
$\begin{array}{l}\text { Histopathology of } \\
\text { Endometrium }(\mathbf{n}-68)\end{array}$ & No. of cases & Percentage \\
\hline Atrophic & 1 & 1.5 \\
\hline Interval & 1 & 1.5 \\
\hline Proliferative & 27 & 35.3 \\
\hline Secretory & 39 & 57.4 \\
\hline Total & 68 & 100 \\
\hline
\end{tabular}

Table 7: USG finding in co relation with histopathology report.

\begin{tabular}{|l|c|l|l|l|l|}
\hline \multicolumn{5}{|c|}{ USG } & \multicolumn{3}{c|}{ Sinal Histopathology report } \\
\hline \multirow{2}{*}{ Bulky } & $\mathrm{N}$ & 21 & 7 & Total \\
\cline { 2 - 5 } & $\%$ & 53.8 & 25.9 & 28 \\
\hline \multirow{3}{*}{ Normal } & $\mathrm{N}$ & 18 & 20 & 42.4 \\
\cline { 2 - 5 } & $\%$ & 43.6 & 77.8 & 38 \\
\hline \multirow{3}{*}{ Total } & $\mathrm{N}$ & 39 & 27 & 57.6 \\
\cline { 2 - 5 } & $\%$ & 100 & 100 & 66 \\
\hline
\end{tabular}

Table 8: Hysteroscopy efficacy chart.

\begin{tabular}{|c|c|c|c|c|}
\hline \multirow{2}{*}{\multicolumn{2}{|c|}{$\begin{array}{l}\text { Hysteroscopy } \\
\text { polyp + fibroid }\end{array}$}} & \multicolumn{3}{|c|}{ Final Histopathology report } \\
\hline & & \multirow{2}{*}{$\begin{array}{l}\text { Secretory } \\
9\end{array}$} & \multirow{2}{*}{$\begin{array}{l}\text { Proliferative } \\
6\end{array}$} & \multirow{2}{*}{$\begin{array}{l}\text { Total } \\
15\end{array}$} \\
\hline Abnormal & $\mathbf{N}$ & & & \\
\hline roid) & $\%$ & 23.1 & 22.2 & 22.7 \\
\hline \multirow[t]{2}{*}{ Normal } & $\mathrm{N}$ & 18 & 20 & 38 \\
\hline & $\%$ & 43.6 & 77.8 & 57.6 \\
\hline \multirow[t]{2}{*}{ Total } & $\mathrm{N}$ & 39 & 27 & 66 \\
\hline & $\%$ & 100 & 100 & 100 \\
\hline
\end{tabular}

Hysteroscopy is much more sensitive than USG in detecting polyp as shown in Table 9.
In 42 cases i.e. in $60 \%$ of cases uterine pathology can be suspected on clinical examination only as shown in Table 10.

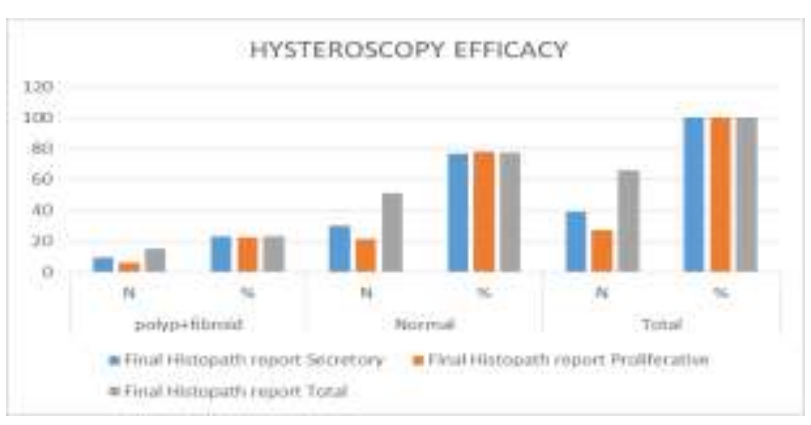

Figure 2: Hysteroscopy efficacy.

Table 9: Detection of polyp by various modalities.

\begin{tabular}{|lll|}
\hline $\begin{array}{l}\text { Method } \\
\text { Polyp diagnosed by } \\
\text { hysteroscopy }\end{array}$ & 14 & 100 \\
\hline Polyp diagnosed by USG & 6 & 42.85 \\
\hline Histopathology & 14 & 100 \\
\hline Total & 14 & 100 \\
\hline
\end{tabular}

Table 10: Local examination finding.

\begin{tabular}{|ll|l|}
\hline Local Examination & No. of Patients & Percentage \\
\hline Bulky & 31 & 44.3 \\
\hline Bulky with Polyp & 6 & 8.6 \\
\hline Fibroid & 2 & 2.9 \\
\hline normal & 28 & 40.0 \\
\hline Normal with Polyp & 3 & 4.3 \\
\hline Total & 70 & 100 \\
\hline
\end{tabular}

After analysing the different parameters for the evaluation of a case of abnormal uterine bleeding, following results are summarized.

A. Most common age of AUB is 30-40 years

B. Most common pattern of AUB is menorrhagia

C. Oligo menorrhea is common in age $<20$ years, menorrhagia is common in age group of 30-50 years. Menorrhagia and postmenopausal bleeding are common after the age of 50 years.

D. AUB is more common in multiparous women.

E. Past menstrual cycle was normal in most of the patient.

F. Common uterine pathology to cause AUB is fibroid uterus.

G. Ultrasonography has a sensitivity of $63 \%$ to detect the cause of AUB.

H. Hysteroscopy sensitivity to know the cause of AUB is $45.45 \%$.

I. Hysteroscopy has a greater sensitivity the ultrasonography to detect intracavitary lesion such as polyp. 
J. Hysteroscopy has an equal $1.4 \%$ chance of developing procedure related complication and anesthesia related complication respectively.

\section{DISCUSSION}

Abnormality of bleeding can be defined as abnormality of regularity and frequency of onset, duration and volume of menstrual flow. In our present study 70 women with abnormal uterine bleeding were examined as they presented in OPD. Ultrasonography and inpatient hysteroscopy were the two methods used to evaluate the causes of AUB. We have tried to develop an algorithmic approach for evaluation of AUB and suggest guidelines to know which patients will need an invasive hysteroscopy and which patient can be evaluated in a less invasive and more cost effective way. We have also attempted to narrow down the differential diagnosis for etiology of abnormal uterine bleeding only on clinical criteria. Multiple other studies have mentioned methods to evaluate a case of abnormal uterine bleeding and some are also done to compare ultrasonography and hysteroscopy as a method to evaluate AUB.

Table 11 shows comparison between 8 studies that were done to evaluate the etiology of abnormal uterine bleeding. Efficacy of ultrasonography and hysteroscopy for the evaluation of etiology of abnormal uterine bleeding were compared.

Present study and study by Patil et al have reported 3140 years as most common age group and multigravida status as the common patient profile for cases of abnormal uterine bleeding. ${ }^{9}$

Our study and two other studies done by Patil et al and the other by Bhosale et al found menorrhagia to be the most common pattern of abnormal uterine bleeding. ${ }^{9,13}$

In our study the most common endometrial histopathology pattern that was found related to AUB was secretory endometrium. It was found in $57 \%$ of our cases whereas in Patil et al study endometrial hyperplasia was most commonly $(40 \%)$ associated with AUB. $^{9}$ In our study we were not able to find any malignancy on histopathological examination. Fibroid uterus is the most common cause of AUB as seen from our results and that was also found in the study done by Haq et al. ${ }^{11}$

In our study USG had a greater sensitivity than hysteroscopy for evaluation of the cause of abnormal uterine bleeding, sensitivity of USG to diagnose the causes of AUB is $63 \%$ and specificity $78 \%$ with positive and negative predictive value of $75 \%$ \& $55 \%$ respectively, while in a similar study done by Haq et al sensitivity to detect cause of AUB is 93\% with specificity $80 \% .^{11}$
When compared with other studies, sensitivity of USG is less in our study probably because we were unable to remove the variable of experience of the sonologist as our institute is a teaching institute and most of the sonography was done by a resident doctor and different sonologists were involved for different cases.

In our present study it was observed that for intracavitary lesion especially uterine polyps, hysteroscopy is highly sensitive; $100 \%$ as compared to USG that has a sensitivity of $43 \%$ only, in a similar study done by Mathlouthi $\mathrm{N}$ et al sensitivity of hysteroscopy for intracavitary lesion is $93 \%$. $^{16}$

This study is different from the other studies as we could clinically (Table 10) in $62 \%$ of the cases detect uterine pathology as cause of abnormal uterine bleeding. This was then corroborated by the histopathology diagnosis. Hence clinical detection of cause of AUB can aid in selecting patients in whom unnecessary expensive investigations can be avoided.

By analysing all the parameters of present study and by observing the results, we developed an algorithm for evaluation of AUB. This algorithm is based on the age wise distribution of AUB in Figure 3 and 4.

Our study had only one patient younger than 20 years of age presenting with AUB so we have excluded this age group from the designed algorithm.

Age $>20$ years is divided in two groups:

A. 20-40 years (reproductive age group) in Figure 3 .

B. >40 years (perimenopausal and menopausal age group) as in Figure 4.

Key interpretations of the algorithm Figure 3 and 4 are as follow.

(i) Pregnancy can be confirmed by simple urine pregnancy test or by ultrasonography.

(ii) If history indicates a bleeding disorder it can be confirmed by laboratory coagulation studies, if suspecting other disease like Von Will brand's disease test for Von Will brand's factor, ristocetin factor and other test for coagulopathy should be done.

(iii) If suspecting liver disease or renal dysfunction as a cause of bleeding it can be confirmed or excluded by doing liver function and renal function tests.

(iv) Thyroid function test can be done to rule out thyroid disorder.

If a patient of abnormal uterine bleeding is not responding to medical line of management or dilatation 
and curettage as shown in above algorithm they can be given option for further management by surgical or conservative approach depending upon their duration and severity of symptom, endometrial histopathology and patients' desire for surgical or conservative management.

Table 11: Comparison table of different studies for evaluation of abnormal uterine bleeding.

\begin{tabular}{|c|c|c|c|c|c|c|c|c|c|}
\hline Study & $\begin{array}{l}\text { Rajesh } \\
\text { et al }{ }^{9}\end{array}$ & $\begin{array}{l}\text { Emanu } \\
\mathrm{l} \mathrm{MH} \\
\text { et al }\end{array}$ & $\begin{array}{l}\text { Kulsu-m } \\
\text { Haq et } \\
\text { al }^{11}\end{array}$ & $\begin{array}{l}\text { Saidi } \\
\text { MH et } \\
\text { al }^{12}\end{array}$ & $\begin{array}{l}\text { Archa- } \\
\text { na } \\
\text { Bhosl-e } \\
\text { et al }\end{array}$ & $\begin{array}{l}\text { Maria } \\
\text { Silveir-a } \\
\text { Feitosl et } \\
\text { al }^{14}\end{array}$ & $\begin{array}{l}\text { Ziad } \\
\text { Shraide- } \\
\text { h MD et } \\
\text { al }^{15}\end{array}$ & $\begin{array}{l}\text { Mathl- } \\
\text { outhi N } \\
\text { et al }^{16}\end{array}$ & $\begin{array}{l}\text { Present } \\
\text { study }\end{array}$ \\
\hline $\begin{array}{l}\text { Most } \\
\text { common } \\
\text { age group }\end{array}$ & $\begin{array}{l}31-40 \\
\text { Years } 45 \%\end{array}$ & & & & & & & & $\begin{array}{l}31-40 \\
\text { Years } \\
37 \%\end{array}$ \\
\hline $\begin{array}{l}\text { Most } \\
\text { common } \\
\text { pattern of } \\
\text { AUB }\end{array}$ & $\begin{array}{l}\text { menorrhagia } \\
73 \%\end{array}$ & & & & $\begin{array}{l}\text { menorrha } \\
\text { gia } \\
53 \%\end{array}$ & & & & $\begin{array}{l}\text { Memo } \\
\text { rrhagia } \\
39 \%\end{array}$ \\
\hline $\begin{array}{l}\text { Parity relation } \\
\text { to AUB } \\
\text { (most } \\
\text { common } \\
\text { parity) }\end{array}$ & $\begin{array}{l}\text { Multi } \\
71 \%\end{array}$ & & & & & & & & $\begin{array}{l}\text { Multi } \\
61 \%\end{array}$ \\
\hline $\begin{array}{l}\text { Most common } \\
\text { intrauterine } \\
\text { cause }\end{array}$ & & & Fibroid & & & & & & Fibroid \\
\hline $\begin{array}{l}\text { Most common } \\
\text { histopathologi } \\
\text { cal finding } \\
\text { of } \\
\text { endometrium }\end{array}$ & $\begin{array}{l}\text { Hyper } \\
\text { Plasia-40\% }\end{array}$ & & & & & & & & $\begin{array}{l}\text { Secretor } \\
\mathrm{y} \\
57 \%\end{array}$ \\
\hline $\begin{array}{l}\text { Sensitivity of } \\
\text { USG for AUB } \\
(\%)\end{array}$ & & $\begin{array}{l}\text { SN-96 } \\
\text { SP-89 }\end{array}$ & $\begin{array}{l}\text { SN-94 } \\
\text { SP-80 } \\
\text { PPV-91 } \\
\text { NPV-85 }\end{array}$ & $\begin{array}{l}\text { SN-95 } \\
\text { SP-65 }\end{array}$ & & & & & $\begin{array}{l}\text { SN-63 } \\
\text { SP-78 } \\
\text { PPV-75 } \\
\text { NPV55 }\end{array}$ \\
\hline $\begin{array}{l}\text { Sensitivity of } \\
\text { hystero- } \\
\text { scopy for } \\
\text { AUB (in } \\
\text { percent) }\end{array}$ & & & & $\begin{array}{l}\text { SN-78 } \\
\text { SP-54 }\end{array}$ & & & & & $\begin{array}{l}\text { SN-45 } \\
\text { SP-78 } \\
\text { PPV-60 } \\
\text { NPV-41 }\end{array}$ \\
\hline $\begin{array}{l}\text { Sensitivity of } \\
\text { USG for intra- } \\
\text { cavitatory } \\
\text { lesion }(\%)\end{array}$ & & & & & & $\begin{array}{l}\text { SN-83 } \\
\text { SP-83 }\end{array}$ & & $\begin{array}{l}\text { SN-79 } \\
\text { SP-45 }\end{array}$ & $\begin{array}{l}\text { SN -43 } \\
\text { (Polyp) }\end{array}$ \\
\hline $\begin{array}{l}\text { Sensitivity } \\
\text { of hystero } \\
\text { Scopy for } \\
\text { Intra- } \\
\text { cavitatory } \\
\text { lesion (in } \\
\text { percent) }\end{array}$ & & & & & & $\begin{array}{l}\text { Sono } \\
\text { Hyster-o } \\
\text { graphy } \\
\text { Better } \\
\text { than } \\
\text { USG }\end{array}$ & $\begin{array}{l}\text { Hystero } \\
\text { Scopy } \\
\text { better than } \\
\text { USG }\end{array}$ & $\begin{array}{l}\text { SN-95 } \\
\text { SP-83 }\end{array}$ & $\begin{array}{l}\text { SN-100 } \\
\text { (Polyp) }\end{array}$ \\
\hline
\end{tabular}




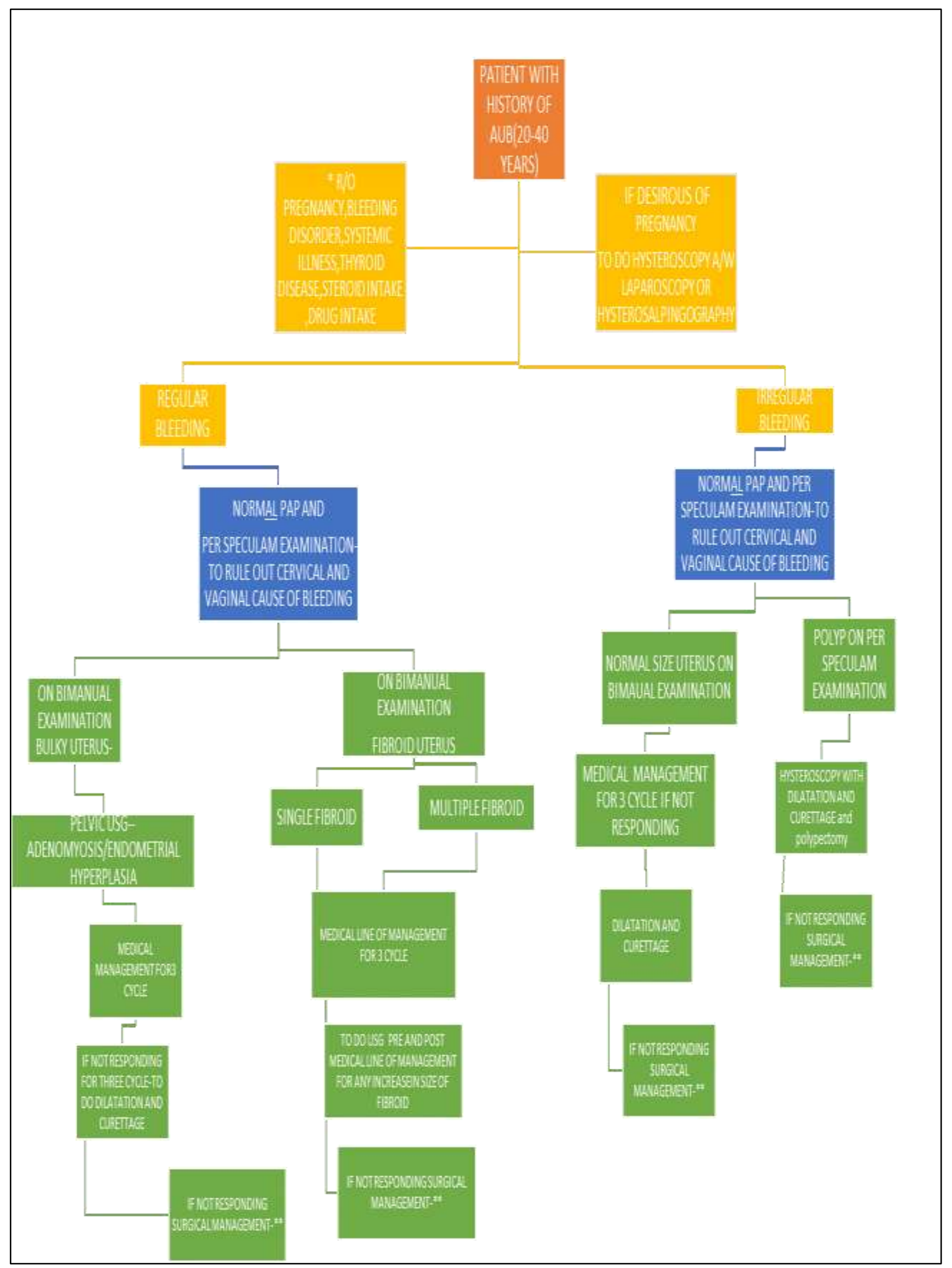

Figure 3: Evaluation of AUB of reproductive age group. 


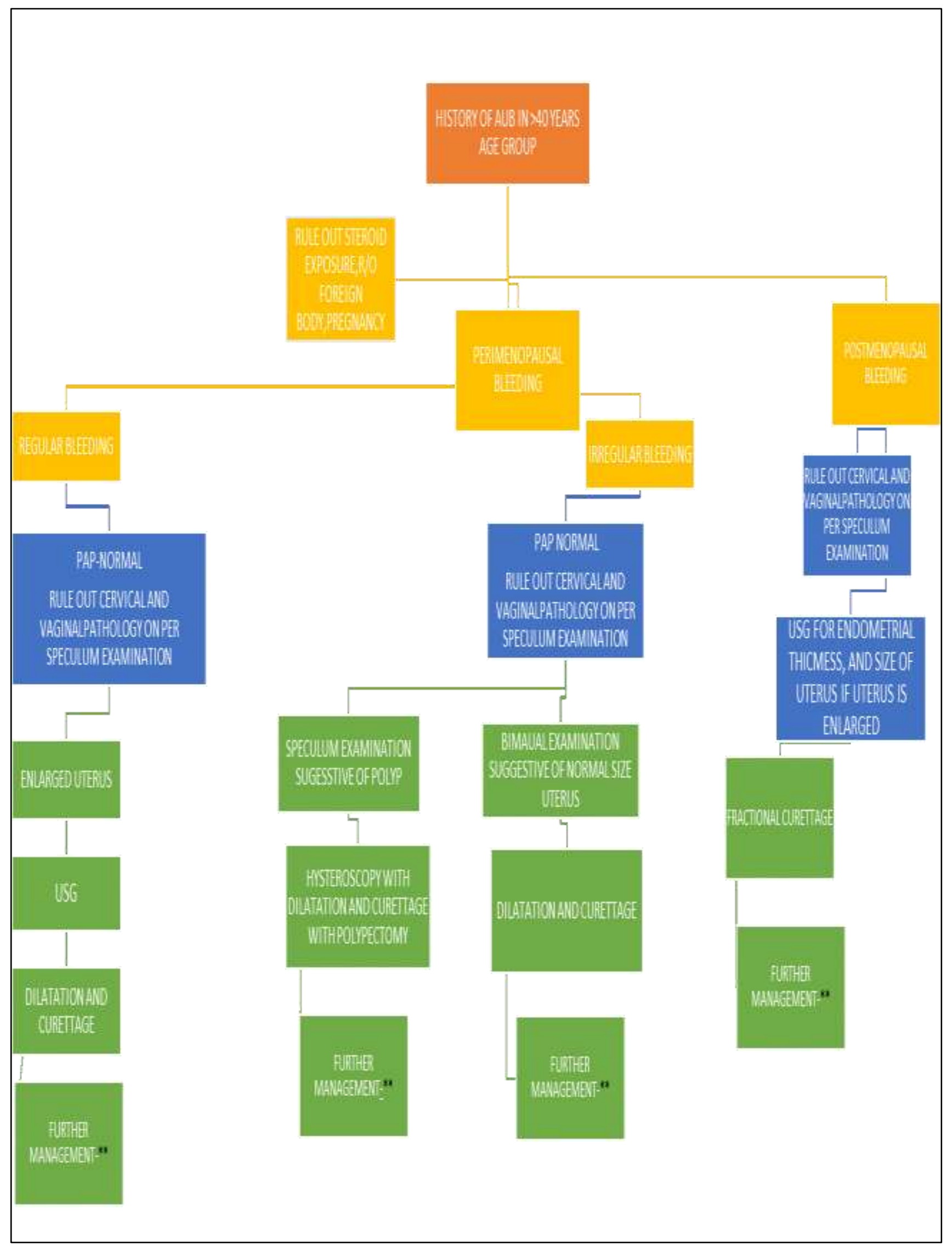

Figure 4: Evaluation of AUB of perimenopausal and menopausal age group. 


\section{CONCLUSIONS}

Each and every case of abnormal uterine bleeding should be evaluated properly. Most of the time abnormal uterine bleeding is due to a benign pathology. However, heavy bleeding can cause severe deterioration in the health of the woman, it can increase the morbidity and hence decreases the socio-economic condition of the family and the society. Few malignant conditions can also be a reason behind the AUB and these need to be diagnosed in time and treated so as to reduce morbidity and risk of mortality.

Ultrasonography is better in detecting the cause of abnormal uterine bleeding than hysteroscopy. However, these diagnostic modalities aid in cases were the clinical diagnosis is not clear. These tests are not required for each and every patient of AUB. A discrete use of these aids tailor made to the patient will not only give the patient optimal diagnosis but will also allow optimal cost effective treatment administration to the patient and also reduce risk of any complications.

We would like to stress that a good clinical history and a thorough clinical examination cannot be replaced by diagnostic investigations like ultrasonography and hysteroscopy.

With the results of this study an algorithm has been developed for systemic scientific, cost effective, patient friendly approach for the evaluation of uterine cause of abnormal uterine bleeding.

\section{ACKNOWLEDGEMENTS}

We acknowledge the Department of Radiology for their contribution in doing sonography of our selected patients. Sonography is one of the diagnostic procedures used for the evaluation of abnormal uterine bleeding and permission for which was taken from ethics committee.

Funding: No funding sources Conflict of interest: None declared

Ethical approval: The study was approved by the Institutional Ethics Committee

\section{REFERENCES}

1. Stovall TG, Photopulos GJ, Poston WM, Ling FW, Sandles LG. Pipelle endometrial sampling in patients with known endometrial carcinoma. Obstet Gynecol. 1991;77(6):954-6.

2. Lerner JP, Timor-Tritsch IE, Monteagudo A. Use of transvaginal Sonography in the evaluation of endometrial hyperplasia and carcinoma. Obstet Gynecol Survey .1996;51:718-25.

3. Goldstein SF, Zeltser I, Horan CK, Snyder JR, Schwartz LB. Ultrasonography-based triage for perimenopausal patients with abnormal uterine bleeding. Am J Obstet Gynecol. 1997;177:102-8.

4. Karlson B, Granberg S, Wikland M, Ylostalo P, Torvid K, Marsal K, et al. Transvaginal ultrasound of the endometrium in women with postmenopausal bleeding--a Nordic multicenter study. Am J Obstet Gynecol. 1995;172(5):1488-94.

5. Weber AM, Belinson JL, Bradley LD, Piedmonte MR. Vaginal ultrasonography versus endometrial biopsy in women with postmenopausal bleeding. Am J Obstet Gynecol. 1997;177(4):924-9.

6. Lewis BV. Hysteroscopy for the investigation of abnormal uterine bleeding. Br J Obstet Gynaecol. 1990; 97:283-4.

7. Loffer FD. Hysteroscopy with selective endometrial sampling compared with D\&C for abnormal bleeding: the value of negative hysteroscopic view. Obstet Gynecol. 1989;73:16-20.

8. Langer RD, Pierce JJ, O'Hanlan KA, Johnson SR, Espeland MA, Trabal JF, et al. Transvaginal ultrasonography compared with endometrial biopsy result. Am J Obstet Gynecol. 1995;172(2Pt1):54752.

9. Patil R, Patil RK, Andola SK, Laheru V, Bhandar M. Histopathological spectrum of endometrium in dysfuctional uterine bleeding. Int $\mathrm{J}$ Biol Med Res.2013;4(1):2798-801.

10. Emanuel MH, Verdel MJ, Wamsteker K, Lammes FB. A prospective comparison of transvaginal ultrasonography and diagnostic hysteroscopy in the evaluation of patients with abnormal uterine bleeding: clinical implications. Am J Obstet Gynecol. 1995;172(2pt1):547-52.

11. Haq K, Chowdhury SF, Mannan M, Ivy R, Tasnim KS. Transvaginal ultrasonography is the diagnostic method for evaluation of abnormal uterine bleeding. Journal of Shaheed Suhrawardy Medical College. 2010;2(1):10-2.

12. Saidi MH, Sadler RK, Theis VD, Akright BD, Farhart SA, Villanueva GR. Comparison of sonography, sonohysterography, and hysteroscopy for evaluation of abnormal uterine bleeding. J Ultrasound Med. 1997;16(9):587-91.

13. Bhosle A, Fonseca M. Evaluation and Histopathological Correlation of Abnormal Uterine Bleeding in Perimenopausal Women. Bombay Hospital Journal. 2010;52(1):69-72.

14. Feitosa IMSD, Feitosa HN, Carvalho FHC, Pereira SM, Medeirosm FC. Comparison between transvaginal ultrasonography and sonohysterography in the assessment of patients with abnormal uterine bleeding. Radiol Bras. 2011;44(3):156-62.

15. Ryu J, Kim B, Lee J, Kim S, Lee SH. Comparison of Transvaginal Ultrasonography with Hysterosonography as a Screening Method in 
Patients with Abnormal Uterine Bleeding. Korean J Radiol. 2004;5:39-46 .

16. Mathlouthi N, Slimani O, Ferchichi A, Temime RB, Makhlouf T, Attia L, et al. Postmenopausal bleeding: Comparison between ultrasonography, hysteroscopy and histopathological results. Tunis Med. 2013;91(2):99-103.
Cite this article as: Kumari M, Gupta AS.A prospective comparative study to evaluate the efficacy of ultrasonography \& hysteroscopy and their correlation with the histopathology of endometrium in a case of abnormal uterine bleeding. Int $\mathbf{J}$ Reprod Contracept Obstet Gynecol. 2015;4:1926-35. 